\title{
Nicotine effect on inflammatory and growth factor responses in murine cutaneous wound healing
}

Citation for published version (APA):

Xanthoulea, S., Deliaert, A., Romano, A., Rensen, S. S., Buurman, W. A., \& van der Hulst, R. R. (2013). Nicotine effect on inflammatory and growth factor responses in murine cutaneous wound healing. International Immunopharmacology, 17(4), 1155-1164. https://doi.org/10.1016/j.intimp.2013.10.022

Document status and date:

Published: 01/12/2013

DOI:

10.1016/j.intimp.2013.10.022

Document Version:

Publisher's PDF, also known as Version of record

Document license:

Taverne

Please check the document version of this publication:

- A submitted manuscript is the version of the article upon submission and before peer-review. There can be important differences between the submitted version and the official published version of record.

People interested in the research are advised to contact the author for the final version of the publication, or visit the DOI to the publisher's website.

- The final author version and the galley proof are versions of the publication after peer review.

- The final published version features the final layout of the paper including the volume, issue and page numbers.

Link to publication

\footnotetext{
General rights rights.

- You may freely distribute the URL identifying the publication in the public portal. please follow below link for the End User Agreement:

www.umlib.nl/taverne-license

Take down policy

If you believe that this document breaches copyright please contact us at:

repository@maastrichtuniversity.nl

providing details and we will investigate your claim.
}

Copyright and moral rights for the publications made accessible in the public portal are retained by the authors and/or other copyright owners and it is a condition of accessing publications that users recognise and abide by the legal requirements associated with these

- Users may download and print one copy of any publication from the public portal for the purpose of private study or research.

- You may not further distribute the material or use it for any profit-making activity or commercial gain

If the publication is distributed under the terms of Article $25 \mathrm{fa}$ of the Dutch Copyright Act, indicated by the "Taverne" license above, 


\title{
Nicotine effect on inflammatory and growth factor responses in murine cutaneous wound healing
}

\author{
Sofia Xanthoulea a,c,*, An Deliaert ${ }^{\mathrm{a}}$, Andrea Romano ${ }^{\mathrm{b}}$, Sander S. Rensen ${ }^{\mathrm{c}}$, \\ Wim A. Buurman ${ }^{c}$, Rene' RWJ van der Hulst ${ }^{\mathrm{a}}$ \\ a Department of Plastic Surgery, Maastricht University Medical Center, P.O. Box 5800, 6202 AZ, Maastricht, The Netherlands \\ b GROW, School for Oncology and Developmental Biology, Maastricht University Medical Centre, Maastricht, The Netherlands \\ c Department of Surgery, NUTRIM School for Nutrition, Toxicology E' Metabolism, Maastricht University Medical Centre, Maastricht, The Netherlands
}

\section{A R T I C L E I N F O}

\section{Article history:}

Received 14 June 2013

Received in revised form 3 September 2013

Accepted 15 October 2013

Available online 6 November 2013

\section{Keywords:}

Cytokines

Growth factors

Inflammation

Macrophages

Nicotine

Wound repair

\begin{abstract}
A B S T R A C T
The aim of the current study was to investigate the effect of nicotine in an experimental mouse model of cutaneous injury and healing responses, during the inflammatory phase of repair. Nicotine injection in full-thickness excisional skin wounds minimally affected inflammatory mediators like TNF, IL-6 and IL-12 while it induced a down-regulation in the expression of growth factors like VEGF, PDGF, TGF- $\beta 1$ and TGF- $\beta 2$, and the antiinflammatory cytokine IL-10. Analysis of wound closure rate indicated no significant differences between nicotine and saline injected controls. In-vitro studies using bone marrow derived macrophages, resident peritoneal macrophages and RAW 264.7 macrophages, indicated that nicotine down-regulates TNF production. Moreover, nicotine was shown to down-regulate VEGF, PDGF and TGF- $\beta 1$ in both bone marrow derived macrophages and RAW 264.7 cells. Using an NF-кB luciferase reporter RAW 264.7 cell line, we show that nicotine effects are minimally dependent on NF- $\kappa$ B inhibition. Moreover, nicotinic acetylcholine receptor (nAChR) subunit expression analyses indicated that while $\beta 2 \mathrm{nAChR}$ subunit is expressed in mouse macrophages, $\alpha 7 \mathrm{nAChR}$ is not. In conclusion, while skin inflammatory parameters were not significantly affected by nicotine, a down-regulation of growth factor expression in both mouse skin and macrophages was observed. Reduced growth factor expression by nicotine might contribute, at least in part, to the overall detrimental effects of tobacco use in wound healing and skin diseases.
\end{abstract}

(c) 2013 Elsevier B.V. All rights reserved.

\section{Introduction}

Cutaneous wound healing after an injury is a complex and highly dynamic process that involves interaction of different players like resident cells of the skin, inflammatory leukocytes, extracellular matrix components and soluble mediators. The healing process can be divided in three consecutive and partially overlapping phases i.e. inflammatory phase, proliferative phase and remodelling phase. The repair process finally results in the formation of a mass of fibrotic tissue known as scar $[1,2]$.

Numerous experimental and clinical studies have determined that inflammation plays a crucial although still not completely clear role during cutaneous wound healing and influences the quality of the resulting scar. Inflammatory cells and particularly macrophages appear to be essential for proper healing by, among other mechanisms, stimulating

Abbreviations: TNF, tumor necrosis factor; IL-6, interleukin 6; IL-12, interleukin 12; VEGF, vascular endothelial growth factor; PDGF, platelet derived growth factor; TGF- $\beta 1$, transforming growth factor beta 1 ; TGF- 32 , transforming growth factor beta 2 .

* Corresponding author at: Maastricht University Medical Centre, Universiteitssingel 50, Maastricht 6229 ER, The Netherlands. Tel.: + 31433882128 ; fax: + 31433884154.

E-mail address: sofia.xanthoulea@maastrichtuniversity.nl (S. Xanthoulea). growth factor and anti-inflammatory cytokine production that are necessary for repair [3]. Moreover, pathological functioning of macrophages and excessive inflammation in the wound healing process can result in derailed healing, like the formation of ulcers, chronic wounds, hypertrophic scars and keloids [4].

Nicotine, a major constituent of tobacco smoke, has been shown to exert anti-inflammatory effects on different cell types and to be beneficial in disorders where inflammation-related mechanisms are involved like in ulcerative colitis and obesity [5]. Nicotine actions are mediated through binding to cholinergic receptors termed nicotinic acetylcholine receptors (nAChR) that are expressed in many different tissues and cells in the body, including immune cells. In both human and mouse macrophages, nicotine was shown to inhibit the release of pro-inflammatory cytokines through a specific "nicotinic anti-inflammatory pathway" that involves signalling through the $\alpha 7 \mathrm{nAChR}$ and prevents activation of the NF- $\kappa B$ pathway [6-9]. In human microvascular endothelial cells, nicotine was found to inhibit TNF-induced NF- $\kappa B$ activation, to suppress adhesion molecule and chemokine expression and to reduce adhesion of leukocytes to activated endothelium and consequent inflammation [10]. Moreover, nicotine was shown to have angiogenic effects and to increase endothelial cell proliferation and vascular growth in different in-vitro and in-vivo models [11,12]. 
In the skin, effects of nicotine are ambivalent and often unclear, but they generally appear more negative than positive. Although cigarette smoking has been reported to negatively affect cutaneous wound healing [13], the angiogenic action of nicotine prompted for studies for a potential beneficial role of nicotine in this process. It was reported that in either normal C57BL/6 [14] or genetically diabetic mice [15], nicotine promotes wound healing due to increased angiogenesis. Yet the effect of nicotine administration on wound inflammatory responses was not evaluated in these studies. Moreover, we have observed that scar formation, a process largely dependent on the extent of the preceding inflammatory process [16], appears to be improved in smokers, which tend to have faster and less erythemateous scar healing compared to non-smokers [17].

In the present study, we aimed to evaluate the effect of nicotine during the inflammatory phase of cutaneous wound healing responses in mice. Quantification of wound closure rate indicated that nicotine did not significantly affect the wound healing process. However, nicotine administration in wounds was found to negatively regulate the production of growth factors like VEGF, PDGF, TGF- $\beta 1$ and TGF- $\beta 2$ but to only minimally affect wound inflammatory parameters. In-vitro, in both primary mouse macrophages and in the macrophage cell line RAW 264.7, nicotine was also found to induce a down-regulation of growth factor expression and to decrease TNF production. Nicotine mediated effects were found to be independent of NF- $\kappa B$ inhibition and the expression of the $\alpha 7 \mathrm{nAChR}$.

\section{Materials and methods}

\subsection{Animals and wound model}

Ten to twelve weeks old C57BL/ 6 female mice $(n=3-4$ mice/ group) were used for experiments. To generate wounds, mice were anesthetized by isofluorane inhalation and the dorsal surface was shaved and cleaned with 70\% ethanol. Full-thickness excisional skin wounds were generated on either side of the dorsal midline using a $3 \mathrm{~mm}$ biopsy punch (Kai medical). Mice were housed individually in special paper bedding material (7089 Harlan Teklad Diamond Soft Bedding), to avoid bedding particles interfering with the healing wounds. Two wounds were generated on the same animal and mice were divided in groups. Mice in each group received only one treatment in both wounds (i.e. saline or nicotine solutions). Solutions were injected with 3 injections of $20 \mu \mathrm{l}$ (total $60 \mu \mathrm{l}$ ) around the wounds once daily for 3 days. Wounds were photographed daily and wound area was quantified using Image J. The percentage of wound closure was calculated using the following formula: Wound closure $(\%)=[$ (wound area on day 0 - wound area on indicated day)/wound area on day 0$] \times 100$. At sacrifice, wounds were excised and snap frozen in liquid $\mathrm{N}_{2}$.
Experiments were performed twice. Mice were maintained under standard pathogen-free conditions and all experiments were approved by the Committee for Animal Welfare of Maastricht University. The investigation conforms to the Guide for the Care and Use of Laboratory Animals published by the US National Institutes of Health (NIH Publication No. 85-23, revised 1996).

\subsection{Reagents}

Nicotine (N3876) and LPS (L2630) were from Sigma-Aldrich Chemie BV (Zwijndrecht, The Netherlands). Nicotine solutions were prepared in culture medium or PBS and were made fresh prior to each experiment. ELISA kits for murine IL-6, IL-10 and IL-12 were purchased from Invitrogen Life Technologies, Inc. (Carlsbad, CA, USA) and performed according to manufacturer's protocol. For murine TNF ELISA a hamster anti-murine TNF monoclonal (TN3) was used as capture antibody and a polyclonal rabbit anti-murine TNF (Genzyme Corporation, Cambridge, MA, USA) was used as a second antibody. The ELISA had a lower detection limit of $50 \mathrm{pg} / \mathrm{ml}$. Quantikine TGF- $\beta 1$ and PDGF-AB ELISA kits (R\&D systems) and VEGF ELISA kit (Life Technologies) were performed according to manufacturer's protocol.

\subsection{Primary cell isolation and cell lines}

For generation of bone marrow derived macrophages (BMDM), bone marrow was isolated from femur and tibia bones of $\mathrm{C} 57 \mathrm{BL} / 6$ mice and cultured in 15-cm bacteriologic plastic petri dishes in RPMI 1640 supplemented with $10 \%$ heat inactivated fetal bovine serum, 100 $\mathrm{U} / \mathrm{ml}$ penicillin, $100 \mu \mathrm{g} / \mathrm{ml}$ streptomycin, $2 \mathrm{mM}$ L-glutamine, $10 \mathrm{mM}$ Hepes and 15\% L-929 cell conditioned medium (LCM) for 8 days. Resident peritoneal macrophages (RPM) were collected from C57BL/6 mice by flushing the peritoneal cavity with $5 \mathrm{ml}$ of ice cold medium. Peritoneal cells were plated in RPMI medium supplemented with antibiotics, L-glutamine and 10\% FCS and macrophages were left to adhere for $4 \mathrm{~h}$. Cells were washed and the remaining macrophages were cultured overnight and stimulated the next day with nicotine and/or LPS for the indicated times. RAW 264.7 cells (American Type Culture Collection, number TIB-71) were cultured in RPMI medium supplemented with antibiotics, L-glutamine and 10\% FCS. 3 T3-L1 murine fibroblasts (American Type Culture Collection, number CL-173) were cultured in DMEM supplemented with antibiotics, L-glutamine and 10\% FCS and SVEC4-10 small-vessel murine endothelial cells (ATCC number CRL2181) were cultured in F12 medium supplemented with antibiotics and 10\% FCS. RAW 264.7 cells stably transfected with the $3 \mathrm{x}-\kappa \mathrm{B}-l u c$ plasmid [18] were a generous gift from Dr. M. de Winther (AMC, Amsterdam).

Table 1

Primer sequences used in this study.

\begin{tabular}{|c|c|c|}
\hline Primer name & Forward sequence & Reverse sequence \\
\hline CD-68 & 5'-TGACCTGCTCTCTCTAAGGCTACA-3' & 5'-TCACGGTTGCAAGAGAAACATG-3' \\
\hline TNF & 5'-CATCTTCTCAAAATTCGAGTGACAA-3' & 5'-TGGGAGTAGACAAGGTACAACCC-3' \\
\hline IL-6 & 5'-TTCAACCAAGAGGTAAAAGATTTACATAA-3' & 5'-CACTCCTTCTGTGACTCCAGCTT-3' \\
\hline IL-12 & 5'-TGAGAACTACAGCACCAGCTTCTT-3' & 5'-CTTCAAAGGCTTCATCTGCAAGT-3' \\
\hline IL-10 & 5'-GCTCTTACTGACTGGCATGAG-3' & 5'-CGCAGCTCTAGGAGCATGTG-3' \\
\hline VEGF & 5'-GCTTTACTGCTGTACCTCCACCA-3' & 5'-GGGACTTCTGCTCTCCTTCTGTC-3' \\
\hline PDGF & 5'-CGCCTGCAAGTGTGAGACAG-3' & 5'-GAATGGTCACCCGAGCTTGA-3' \\
\hline TGF- $\beta 1$ & 5'-GCCCTTCCTGCTCCTCATG-3' & 5'-CCGCACACAGCAGTTCTTCTC-3' \\
\hline TGF- 32 & 5'-GACTTAACATCTCCCACCCA-3' & 5'-CCATCAATACCTGCAAATCTCG-3' \\
\hline$\alpha 7$ nAchR-1 & 5'-CACATTCCACACCAACGTCTT-3' & 5'-AAAAGGGAACCAGCGTACATC-3' \\
\hline$\alpha 7$ nAchR-2 & 5'-TGCTGGTATTCTTGCTGCCTGC-3' & 5'-GGTGCTGGCGAAGTACTGTGCTAT-3' \\
\hline$\alpha 7$ nAchR-3 & 5'-GCCTAAGTGGACCAGGATCA-3' & 5'-CTCGGAAGCCAATGTAGAGC-3' \\
\hline$\beta 2 \mathrm{nAchR}$ & 5'-GGGCAGGCACACTATTCTTC-3' & 5'-TCСAАТССТСССТСАСАCTC-3' \\
\hline cyclophilin & 5'-ТTCСТССТTТАССGAATTATTCCA-3' & 5'-CCGCCAGTGCCATTATGG-3' \\
\hline GAPDH & $5^{\prime}$-TTCACCACCATGGAGAAGGC- $3^{\prime}$ & 5'-GGCATGGACTGTGGTCATGA-3' \\
\hline$\beta$-actin & 5'-GACAGGATGCAGAAGGAGATTACTG-3' & 5'-CCACCGATCCACACAGAGTACTT-3' \\
\hline
\end{tabular}




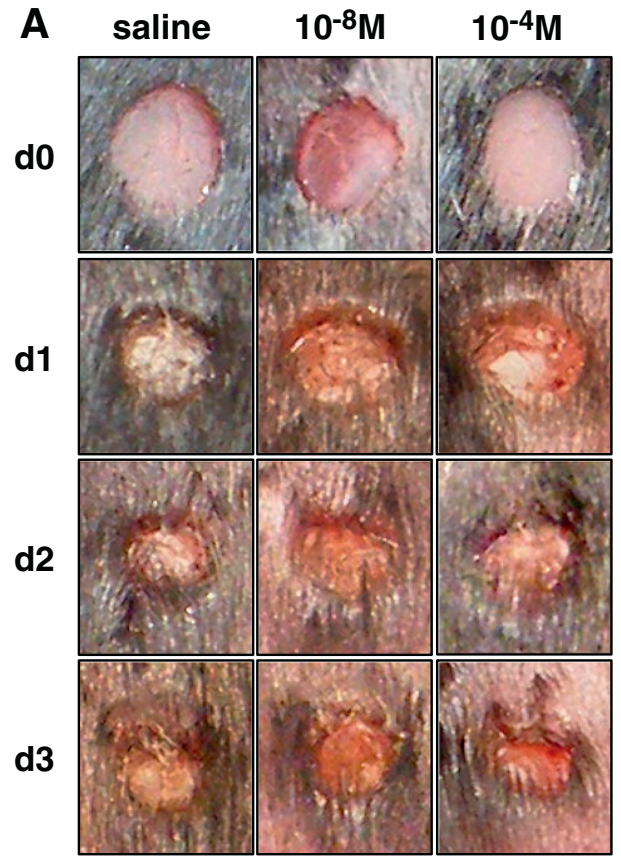

C

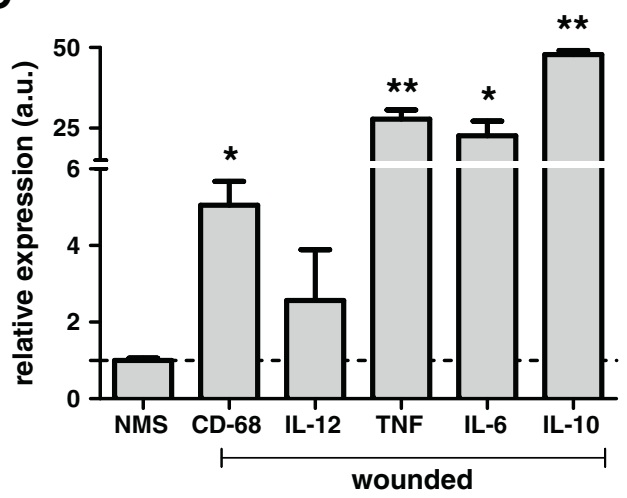

E

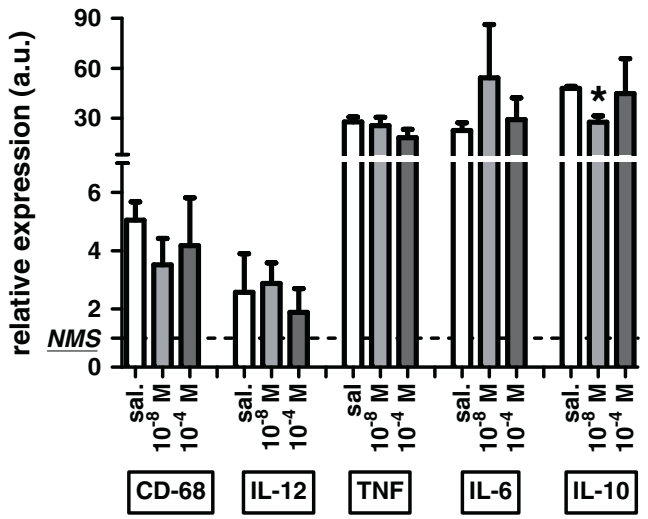

B

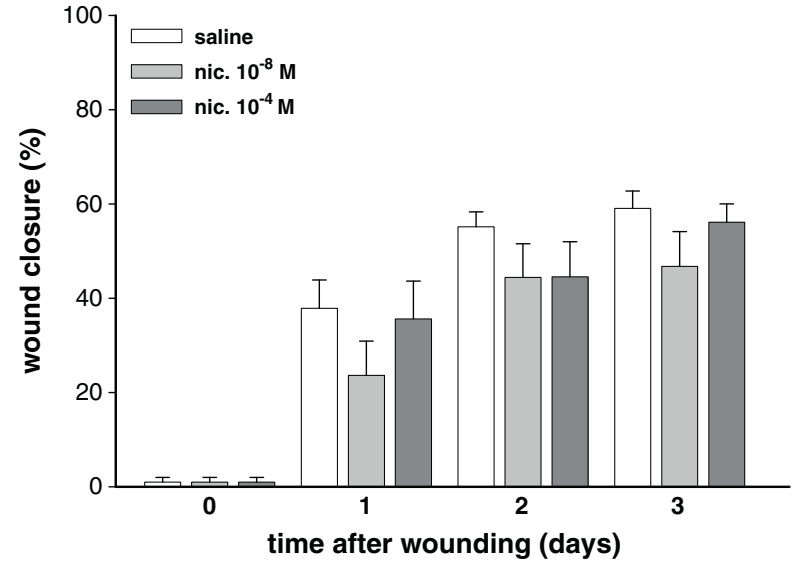

D

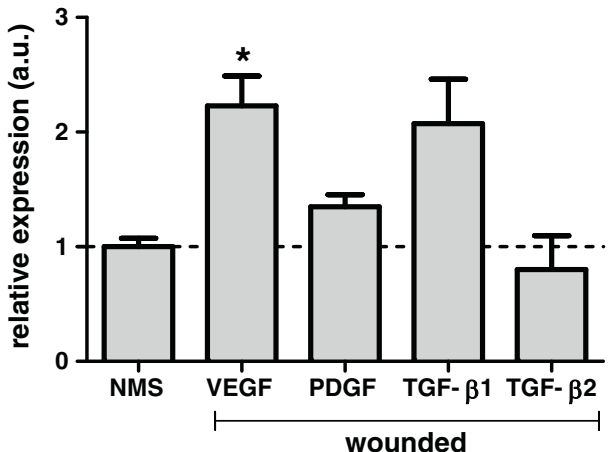

$\mathbf{F}$

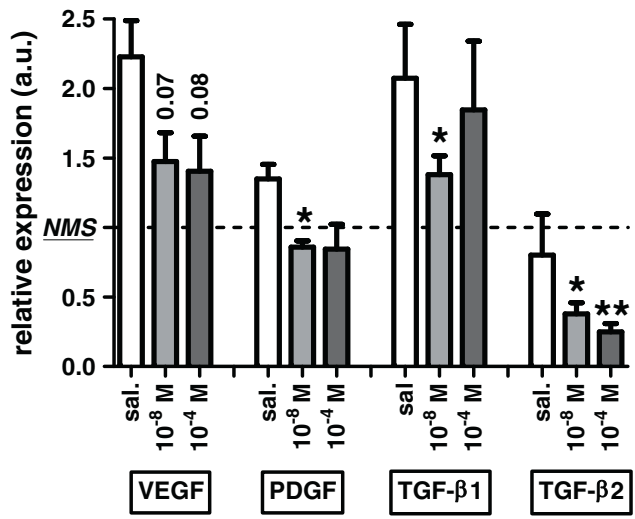

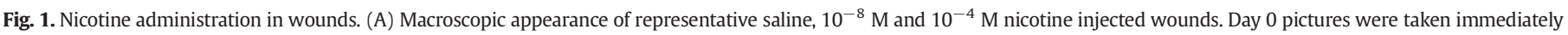

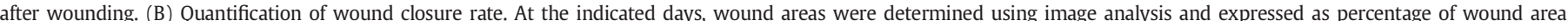

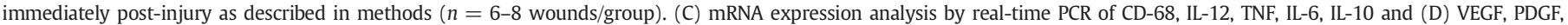

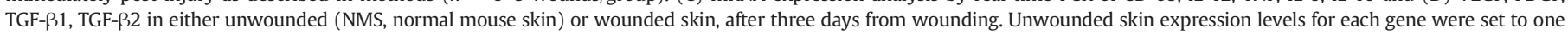

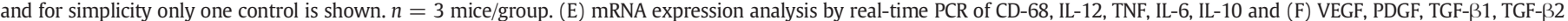

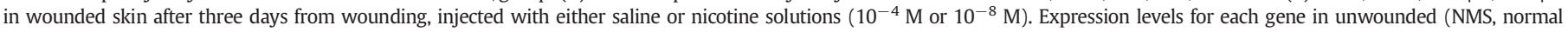

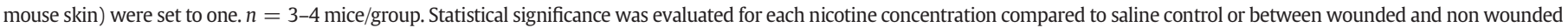
skin, by $t$-test. ${ }^{*} p<0.05,{ }^{* *} p<0.01$. 


\subsection{RNA isolation and quantitative gene expression}

RNA was isolated either with the RNeasy Fibrous Tissue kit (Qiagen $\mathrm{GmbH}$, Hilden, Germany) for mouse skin tissue or with Trizol (SigmaAldrich Chemie BV) for cell monolayers. Residual DNA was digested with the RQ1 RNase-free DNase (Promega GmbH, Mannheim, Germany) and cDNA synthesis was performed using the iScript ${ }^{\mathrm{TM}}$ cDNA synthesis kit (Bio-Rad, Hercules, CA, USA). Quantitative PCR was performed in 10 ng of cDNA, with $1 \times$ Absolute qPCR SYBR Green Fluorescein Mix (Westburg, Leusden, The Netherlands) and $150 \mathrm{nM}$ of gene specific forward and reverse primers. Cyclophilin $A$ and $\beta$-actin were used as housekeeping genes. Primer sequences are indicated in Table 1.

\subsection{MTT assay, luciferase activity and ELISA}

For MTT (3-(4,5-dimethylthiazol-2-yl)-2,5-diphenyl tetrazolium bromide; Sigma-Aldrich Chemie BV) assay, $10^{5}$ cells/well of BMDM, RAW 264.7, PEC or $5 \times 10^{4}$ cells/well of SVEC4-10 or $10^{4}$ cells/well of 3 T3-L1 cells were plated in 96-well plates overnight and stimulated the following day with nicotine and/or LPS (100 ng/ml) for $24 \mathrm{~h}$. Nicotine was added to cell cultures $30 \mathrm{~min}$ before LPS. MTT assay was performed after $24 \mathrm{~h}$ by addition of MTT solution to a final concentration of $0.5 \mathrm{mg} / \mathrm{ml}$, for $2 \mathrm{~h}$. Dye was solubilized with DMSO (SigmaAldrich Chemie BV) and absorbance was measured at $570 \mathrm{~nm}$. Data represent mean \pm SEM of 4 independent experiments performed in triplicate.

For luciferase activity, RAW 264.7 cells stably transfected with the $3 \mathrm{x}-\kappa \mathrm{B}-$ luc plasmid were plated at a density of $10^{5}$ cells/well in 96 well plates and stimulated with the indicated compounds for the indicated times. Cells were lysed in lysis buffer (Promega $\mathrm{GmbH}$ ) for $20 \mathrm{~min}$ and $10 \mu \mathrm{l}$ lysate was added to $50 \mu \mathrm{l}$ luciferin (Steady-Glo Luciferase assay system, Promega $\mathrm{GmbH}$ ). Luciferase activity was measured with a Lumac Biocounter M1500 luminometer (Promega GmbH). Data represent mean \pm SEM of 2 independent experiments performed in quadruplicate.

For ELISA, $2 \times 10^{5} 3$ T3-L1 fibroblast cells or $5 \times 10^{5}$ macrophages or SVEC4-10 endothelial cells were plated in $500 \mu \mathrm{l}$ medium in triplicate/ condition in 24-well plates and stimulated for 6 or $24 \mathrm{~h}$ with nicotine and/or LPS. Supernatants were analyzed by ELISA. Since significant levels of growth factors are present in bovine serum used in tissue culture medium, for quantification of VEGF, PDGF-AB and TGF- $\beta 1$ in macrophage supernatants, medium was changed to Optimem-1 (Gibco-BRL) overnight and cells were stimulated the following morning with nicotine for 6 or $24 \mathrm{~h}$. Experiments were performed in triplicate and data represent mean \pm SEM of 3 independent experiments.

\subsection{Statistical analysis}

Statistical analyses were performed using Graphpad Prism (Graphpad Software) or SigmaPlot statistical tests. Data are expressed as means \pm SEM. A $p<0.05$ is considered statistically significant.

\section{Results}

\subsection{Nicotine down-regulates growth factor expression in skin wounds}

The initial response upon a cutaneous injury is characterized by a strong inflammatory reaction with induction of different inflammatory
A

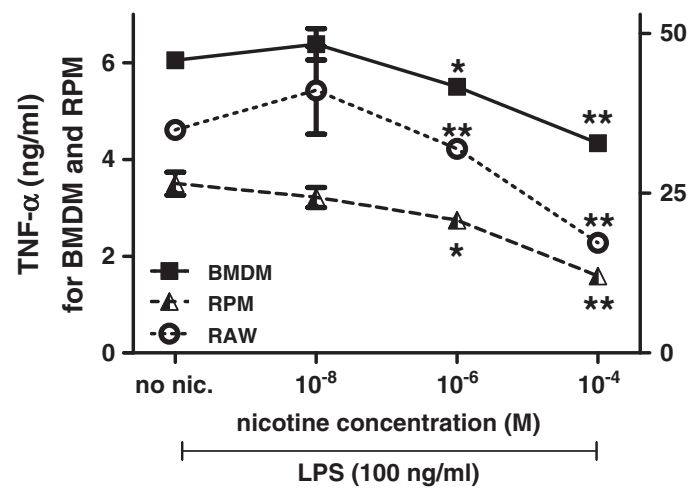

C

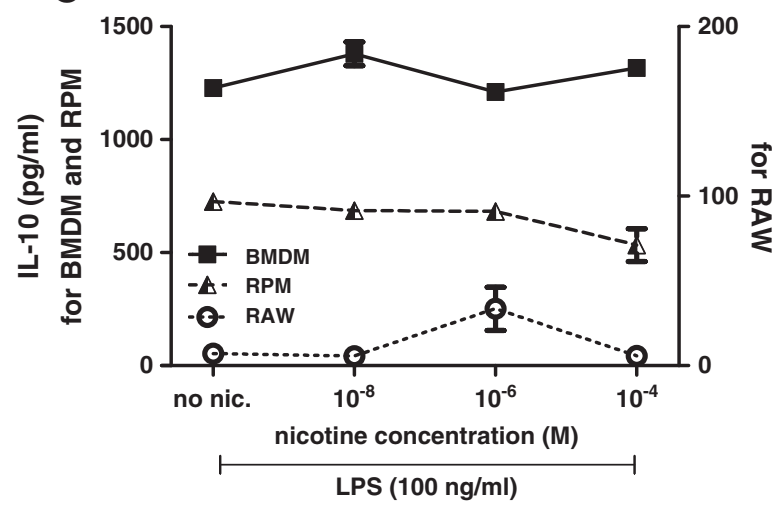

B

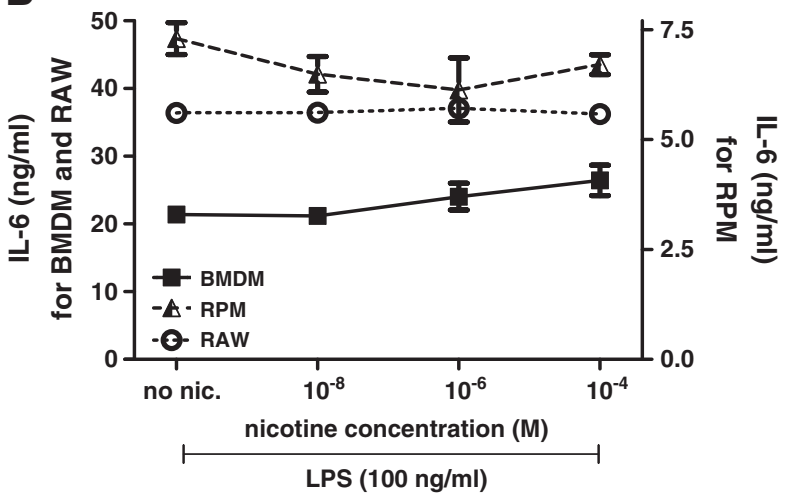

D

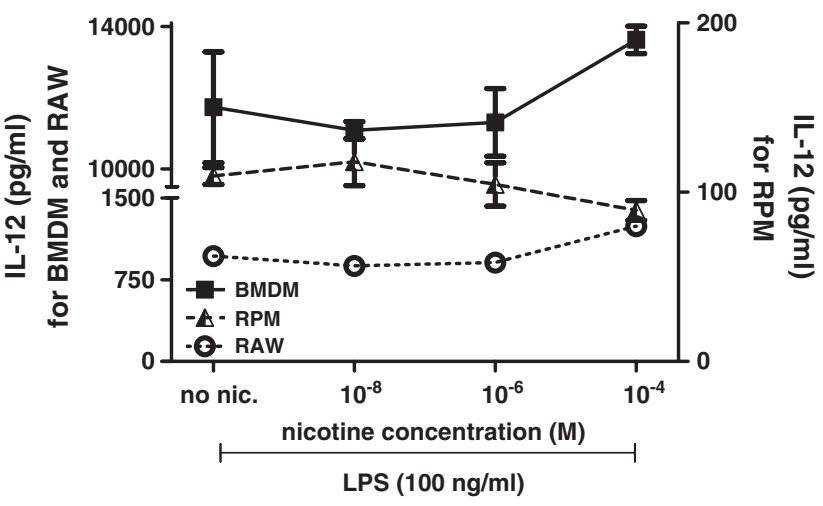

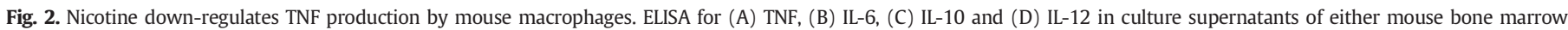

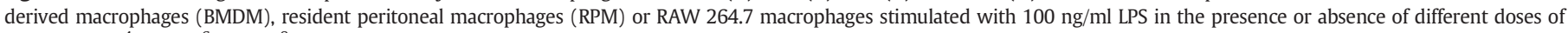

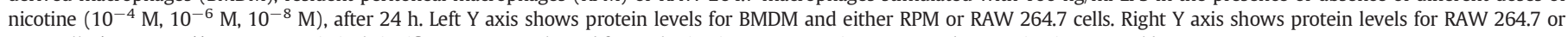
RPM cells. ${ }^{*} p<0.05,{ }^{* *} p<0.01$. Statistical significance was evaluated for each nicotine concentration compared to no nicotine control by $t$-test. 
mediators. Since nicotine was previously shown to negatively regulate inflammation [6-9], and to promote wound healing in normal [14] and genetically diabetic mice [15], we aimed to examine the effect of nicotine administration during the inflammatory phase of cutaneous wound healing in mice. Full thickness excisional wounds were generated on the dorsum of C57BL/6 mice and mice were divided in groups that received either saline or nicotine solutions. Saline or nicotine solutions at two different concentrations $\left(10^{-4} \mathrm{M}\right.$ or $\left.10^{-8} \mathrm{M}\right)$ were injected around the wounds daily for three days, similar to other studies [14] and as described in the methods section. Quantification of wound area indicated a not significant delay in wound closure in the nicotine injected wounds compared to saline controls (Fig. $1 \mathrm{~A}$ and B). After three days, real time PCR analysis of RNA isolated from either wounded mice or non-wounded controls (normal mouse skin, NMS) was performed. As shown in Fig. $1 \mathrm{C}$, wounded skin exhibits a strong inflammatory response which is absent in non-wounded controls. CD-68 was over five-fold increased indicating extensive macrophage infiltration and expression of different inflammatory mediators (TNF, IL-6, IL-10) was also found several fold increased (Fig. 1C). A milder effect of wounding on expression of growth factors was observed (Fig. 1D).

Nicotine injections resulted in significant mild down-regulation in the expression of IL-10 in the wounds of $10^{-8} \mathrm{M}$ nicotine injected wounds compared to saline controls (Fig. 1E). Interestingly, nicotine administration indicated a clear down-regulation in the mRNA expression of growth factors, with PDGF, TGF- $\beta 1$ and TGF- $\beta 2$ showing significant differences while VEGF expression had a similar trend but differences were borderline not significant (Fig. 1F).
3.2. Nicotine down-regulates TNF and growth factor expression in mouse macrophages

Macrophages play a crucial role during cutaneous wound healing and represent a major source of cytokines and growth factors in the wound [3]. Previous studies have shown that nicotine attenuates macrophage activation and inhibits the production of a number of pro-inflammatory cytokines [7,9]. To evaluate the effect of nicotine in our setting, we used primary mouse macrophages like bone marrow derived (BMDM) and resident peritoneal macrophages (RPM) and the mouse macrophage cell line RAW 264.7. Cells were stimulated with LPS in order to induce cytokine production, and with or without addition of nicotine in the culture medium (nicotine added $30 \mathrm{~min}$. before LPS) for either 6 or $24 \mathrm{~h}$. Nicotine concentrations used were comparable to those in similar studies [7,9] and in the range of nicotine concentrations in blood during smoking [19]. No major effect of nicotine on the production of TNF, IL-6, IL-12 and IL-10 was observed after 6 h, as measured by ELISA in culture supernatants (data not shown). However after $24 \mathrm{~h}$, we could confirm previous studies showing that nicotine induces a significant dose-dependent down-regulation in the production of TNF in all macrophage cells tested (Fig. 2A). No significant effect of nicotine on the production of IL-6, IL-10 or IL-12 was observed (Fig. 2B, C, D).

Since macrophages are major sources of growth factors and nicotine administration in wounds indicated a down-regulation in growth factor expression, we analyzed macrophage growth factor gene expression in the presence of nicotine. Similar to the in-vivo findings, nicotine was
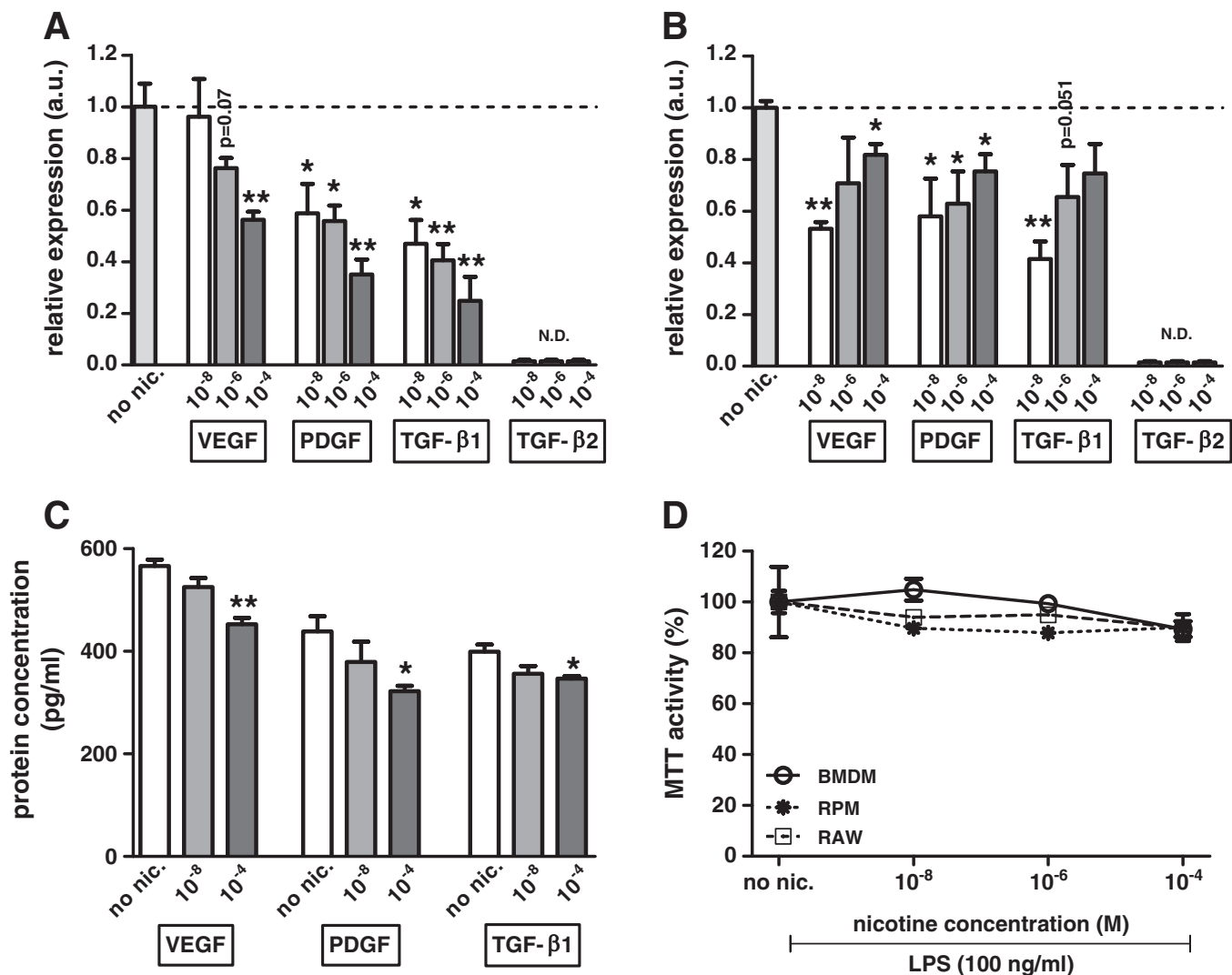

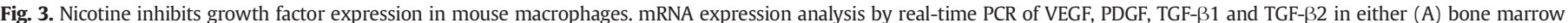

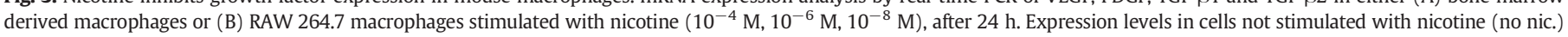

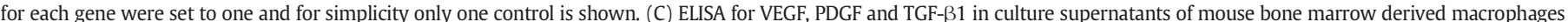

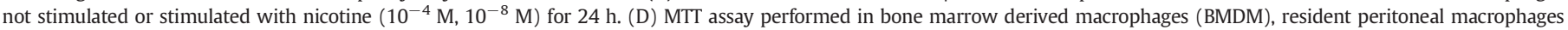

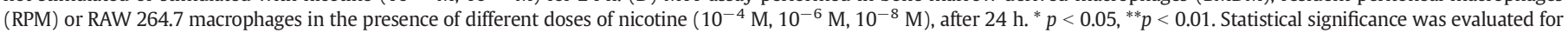
each nicotine concentration compared to no nicotine control by $t$-test. 
found to down-regulate mRNA levels of VEGF, PDGF and TGF- $\beta 1$ in BMDM and RAW 264.7 macrophages (Fig. 3A and B respectively) (TGF- $\beta 2$ levels were undetectable). A comparable down-regulation in the protein levels of VEGF, PDGF and TGF- $\beta 1$ was measured in BMDM culture supernatants after $24 \mathrm{~h}$ of incubation with nicotine (Fig. 3C). Expression levels were below detection limit in supernatants of RAW 264.7 cells. Cell viability measurement by tetrazolium salt MTT assay showed that concentrations of nicotine used did not result in significant differences in cell survival and therefore the observed effects were not due to cytotoxicity (Fig. 3D).

\subsection{Nicotine does not significantly affect NF- $\kappa B$ transcriptional activity in mouse macrophages}

Nicotine has been proposed to inhibit pro-inflammatory gene expression through a nicotinic anti-inflammatory pathway which results in the inhibition of NF- $\kappa \mathrm{B}[8,20]$. Moreover, NF- $\kappa \mathrm{B}$ regulates the expression of a number of growth factors as VEGF and PDGF [21]. To determine the effect of nicotine on NF- $\kappa B$ transcriptional activity we used a macrophage RAW 264.7 cell line stably transfected with an NF- $\kappa B$ luciferase reporter and that expresses luciferase under the control of NF- $\kappa$ B. This cell line maintains the inflammatory characteristics of the parental line used in the previous experiments [18]. As shown in Fig. 4A, nicotine alone (without LPS induction), does not activate NF- $\kappa B$ in any of the concentrations or time points examined (1, 6 or $24 \mathrm{~h}$; for simplicity only the one hour time point is shown). Activation of RAW 264.7 macrophages with LPS induces NF-KB activation already after one hour, as measured by luciferase activity. NF- $\kappa$ B transcriptional activity peaked at six hours and returned to baseline after $24 \mathrm{~h}$. However, nicotine showed only a very mild and statistically non-significant reduction in $\mathrm{NF}-\mathrm{KB}$ activity at one and six hours indicating that NF- $\mathrm{BB}$ inhibition by nicotine is only minimal.

Since nicotine dependent NF- $\kappa$ B inhibition in human macrophages was reported to be mediated by the $\alpha 7$ nicotinic acetylcholine receptor $(\alpha 7 \mathrm{nAChR})[8,20]$, we evaluated the expression of this receptor in the different macrophage cell types used in our study. RNA was isolated from BMDM, RPM and RAW 264.7 cells and PCR was performed on cDNA for the identification of nAChR transcripts. As shown by previous studies [22], while expression of another nicotinic receptor like $\beta 2$ nAChR was detected in mouse macrophages, $\alpha 7$ nAChR transcript was not detected in any of cell types analyzed (Fig. 4B). Use of two additional primer pairs for the $\alpha 7 \mathrm{nAChR}$ failed as well to detect transcripts for this receptor (data not shown; primer sequences listed in Table 1). Similar analysis of RNA isolated from either unwounded or wounded mouse skin confirmed the presence of $\beta 2 \mathrm{nAChR}$ and the absence of $\alpha 7$ $\mathrm{nAChR}$ transcripts in mouse skin.

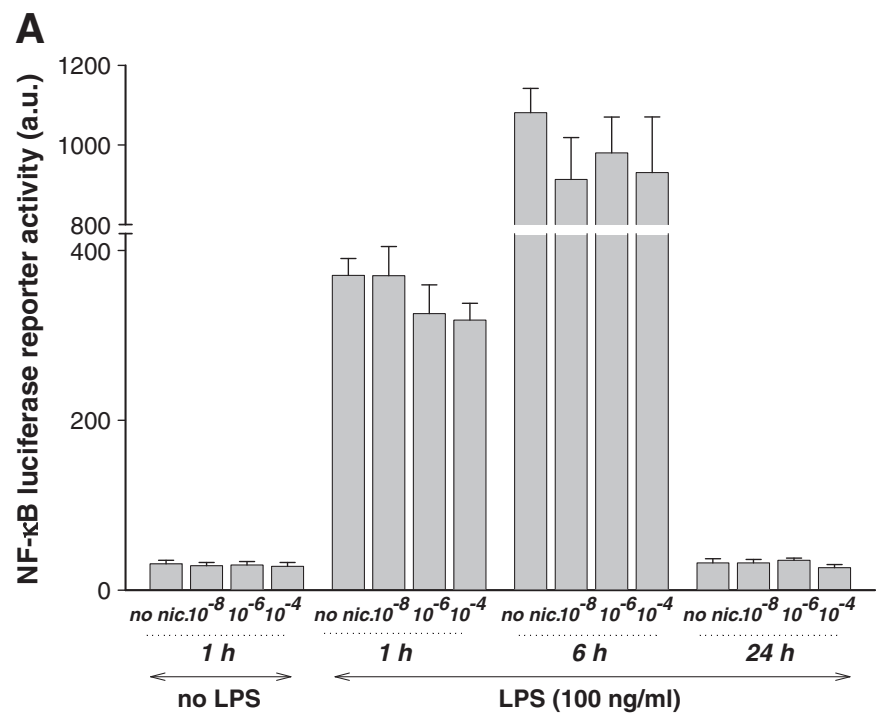

B
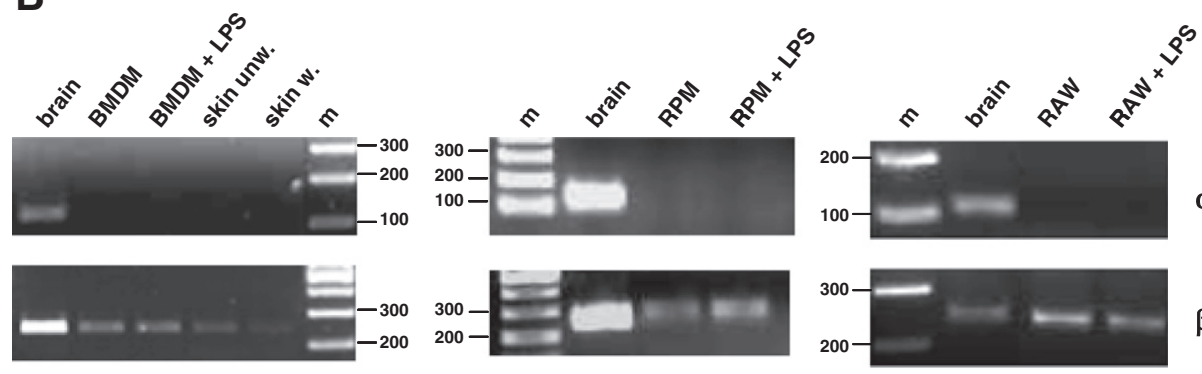

$\alpha 7$ nAChR
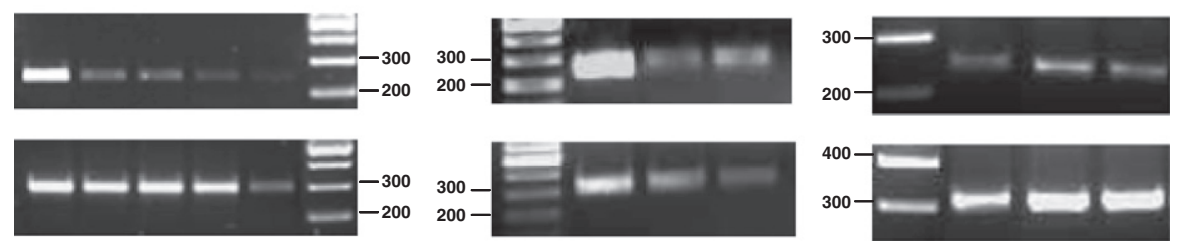

$\beta 2 \mathrm{nAChR}$
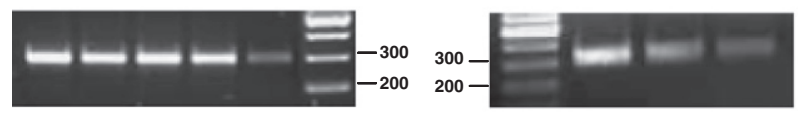

GAPDH

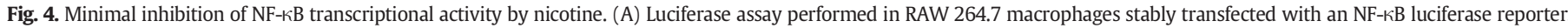

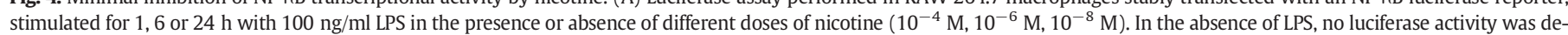

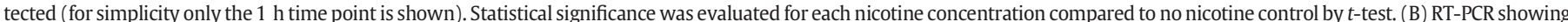

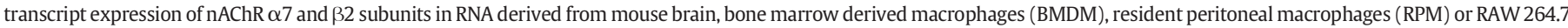

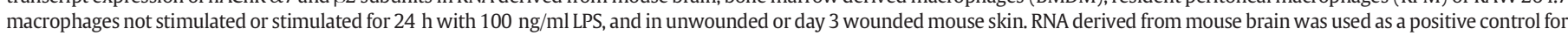
nicotinic acetylcholine receptor expression while GAPDH was used as loading control. 


\subsection{Nicotine effect on endothelial and fibroblast cells}

In addition to macrophages, fibroblasts and endothelial cells are abundantly present in the skin and have pivotal functions in the process of cutaneous wound healing. To evaluate the effect of nicotine on these cell types, we analyzed cytokine responses in the murine endothelial cell-line SVEC4-10 and in 3 T3-L1 murine fibroblasts after LPS activation in the presence or absence of nicotine (nicotine added to the medium 30 min before LPS). In both cell types no detectable amounts of TNF, IL-12 or IL-10 were measured by ELISA after $24 \mathrm{~h}$ of either LPS or LPS and nicotine incubation (not shown). On the contrary, IL-6 was measured in the culture supernatants of both SVEC4-10 cells (Fig. 5A) and 3 T3-L1 fibroblasts (Fig. 6A), but no differences were seen in the presence of different nicotine concentrations. MTT toxicity assay showed that the concentrations of nicotine used $\left(10^{-4} \mathrm{M}, 10^{-6} \mathrm{M}, 10^{-8} \mathrm{M}\right)$ were not toxic to either cell line since toxicity effects were only seen from concentrations higher than $10^{-3} \mathrm{M}$ (Figs. 5B and 6B). Contrarily, MTT assay showed that nicotine actually promoted proliferation of 3 T3-L1 fibroblasts. As shown in Fig. 6B, in the absence of LPS stimulation, nicotine induces an approximately $10-20 \%$ increase in cell proliferation compared to non-treated cells. Addition of LPS to 3 T3-L1 cells induces a similar increase in cell proliferation but there is no further increase if nicotine is added in the presence of LPS.

To evaluate $\alpha 7$ nAChR expression in 3 T3-L1 and SVEC4-10 cells, RNA was isolated from either non-stimulated cells or cells stimulated with LPS for $24 \mathrm{~h}$ and cDNA was synthesized. Neither cell type was found to express $\alpha 7 \mathrm{nAChR}$ mRNA (Figs. 5C and 6C). SVEC4-10 cells expressed the $\beta 2 \mathrm{nAChR}$ transcripts while this nicotinic receptor subunit was absent from 3 T3-L1 fibroblasts. Moreover, real-time PCR analysis of RNA isolated from nicotine stimulated SVEC4-10 or 3 T3-L1 cells indicated that contrary to macrophages, nicotine does not induce a significant down-regulation of growth factors in these cell-types and actually shows a trend towards increased PDGF expression in 3 T3-L1 cells (Figs. 5D and 6D respectively).

\section{Discussion}

The discovery approximately a decade ago of a nicotinic antiinflammatory pathway mediated by the $\alpha 7 \mathrm{nAChR}$ has raised interest in the use of nicotine or nicotinic agonists as potential therapeutic agents in different chronic inflammatory conditions. The therapeutic use of nicotine has been suggested for the treatment of inflammatory disorders such as Crohn's disease, ulcerative colitis and obesity $[5,23]$. However, the potential of a therapeutic role of nicotine in the skin is unclear and controversies exist as to whether the overall effect must be regarded as positive or negative [13].

\subsection{Effect of nicotine on wound healing}

Previous studies regarding the effect of nicotine in cutaneous wound healing responses in mice have shown contradictory results. In one study, day eight wounds treated with $10^{-3} \mathrm{M}$ nicotine solution resulted in delayed wound healing with a larger wound area compared to saline controls, while wounds treated with a nicotine concentration of $10^{-4} \mathrm{M}$ showed improved healing and a smaller wound area. Treatment with nicotine concentrations of $10^{-7} \mathrm{M}$ or $10^{-10} \mathrm{M}$ showed no significant differences [14]. In a different study, nicotine concentrations of $10^{-8} \mathrm{M}$ and $10^{-9} \mathrm{M}$ accelerated wound healing only in genetically diabetic (Lepr ${ }^{\mathrm{db}}$ ) mice but not in control mice (heterozygous for the diabetes allele) compared to saline treated controls [15]. In both studies,
A

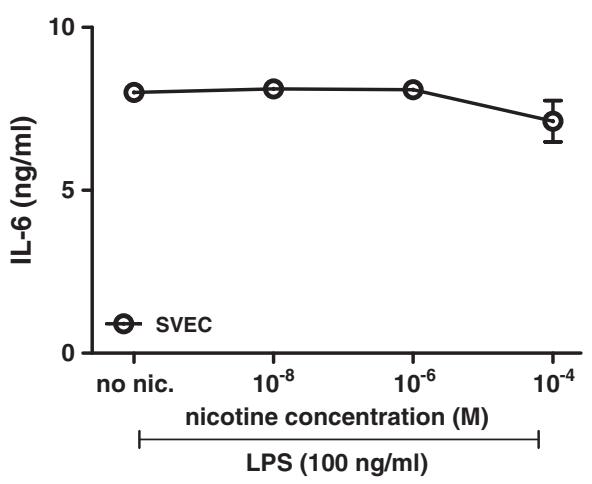

C

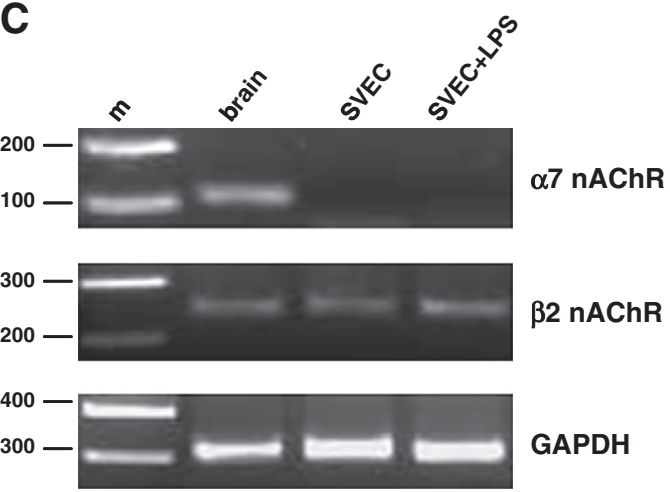

B

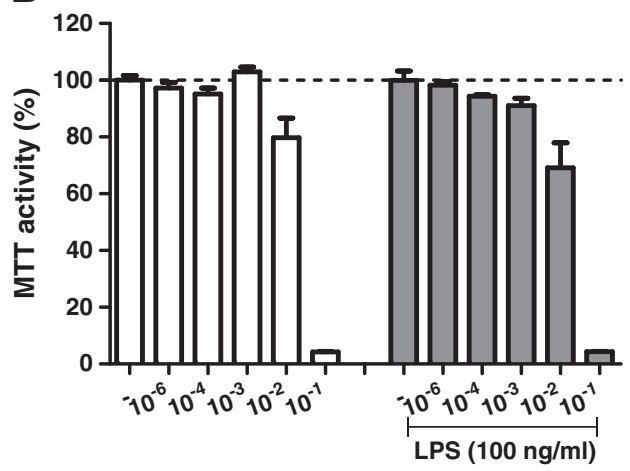

D

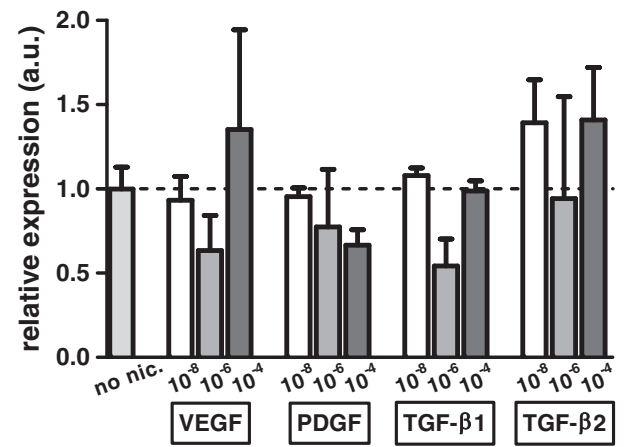

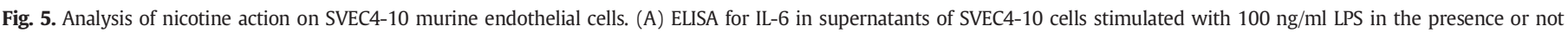

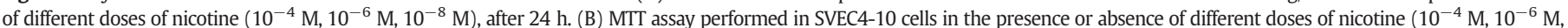

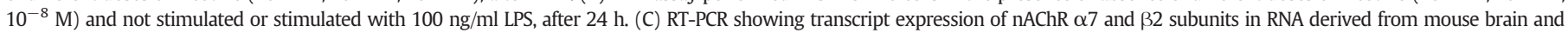

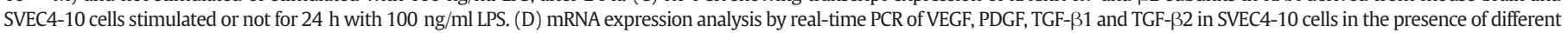
doses of nicotine $\left(10^{-4} \mathrm{M}, 10^{-6} \mathrm{M}, 10^{-8} \mathrm{M}\right)$, after $24 \mathrm{~h}$. Statistical significance was evaluated for each nicotine concentration compared to no nicotine control by $t$-test. 
improved healing was associated with improved wound angiogenesis. In our wound healing experiment we could not observe an improvement in wound healing induced by nicotine treatment in wild type mice compared to controls. Differences with previous studies regard both the background of the mice but also the time-point in which wound area is measured (the first three days in our setting versus days eight or fourteen in other studies). Although no significant dysregulation in wound inflammatory parameters like TNF, IL-6 and IL-12 was detected, nicotine induced a down-regulation in the expression of anti-inflammatory IL-10 and growth factors like VEGF, PDGF, TGF- $\beta 1$ and TGF- $\beta 2$. This latter effect was also confirmed in-vitro in both primary mouse bone marrow derived macrophages and RAW 264.7 cells, at both the RNA and protein levels, while a similar down-regulation was not observed in either fibroblasts or endothelial cells. Therefore, it is likely that the inhibition of growth factor production by wound macrophages accounts for the down-regulation of growth factors observed in nicotine-injected wounds.

\subsection{Nicotine action on growth factor expression}

Previous studies have suggested that the effect of nicotine on growth factor expression is likely to be cell-type specific. Chronic exposure to nicotine was found to reduce plasma VEGF levels in mice and to impair cholinergic angiogenesis [24]. In other studies, while nicotine was shown to induce VEGF and FGF in vascular smooth muscle cells and endothelial cells [25-27], it inhibited VEGF, PDGF and TGF- $\beta 1$ in rabbit osteoblasts [28] and VEGF in porcine retinal pigment epithelium [29]. Moreover, nicotine was shown to upregulate the expression of VEGF but suppress the expression of PDGF in nasopharyngeal carcinoma (NPC) cells [30]. Our data show that in macrophages, a major source of growth factors like VEGF and TGF- $\beta 1$ in wounds [31], the effect of nicotine is inhibitory. In support of a cell-type specific nicotine action, we observed a trend towards increased PDGF production by nicotine in 3 T3-L1 fibroblasts.

\subsection{Nicotine action on monocytes/macrophages}

Nicotine was found to inhibit the production of pro-inflammatory cytokines in human and mouse monocytes or macrophages through activation of a Jak2-STAT3 pathway and inhibition of the NF-kB transcriptional activity $[6-9,20]$. However, discrepancies from these findings in studies where nicotine was shown to augment TNF and proinflammatory synthesis in macrophages exist [32]. Using either primary mouse cells like bone marrow derived macrophages and resident peritoneal macrophages, or the mouse macrophage cell line RAW 264.7, we could confirm previous findings of an inhibitory action of nicotine on TNF production. Using an NF- $\kappa$ B luciferase reporter system, we also show that, although nicotine induces down-regulation of TNF expression in RAW 264.7 macrophages, this is only minimally dependent on inhibition of NF- $\kappa$ B transcriptional activity. Discrepancies from other studies $[8,20]$ that show inhibition by nicotine of NF- $\kappa B$ activity in luciferase assays may be explained by the differences in transiently transfected cells used in those studies compared to the stable transfected line we used in our experiments. Therefore, additional mechanisms to NF- $\kappa B$ suppression seem to be responsible for the nicotine induced down-regulation of TNF expression in macrophages. In line with this, a different mechanism of nicotine mediated suppression of TNF release in human macrophages was recently reported, through induction of tristetraprolin (TTP), an ARE-binding protein that binds and promotes degradation of the TNF transcript [33].
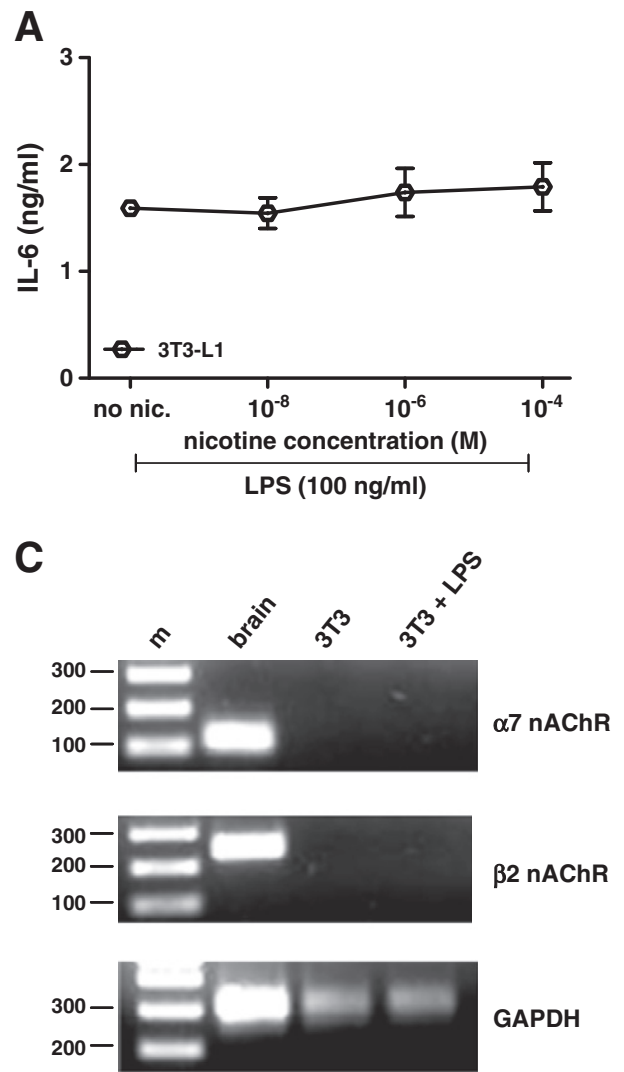

B
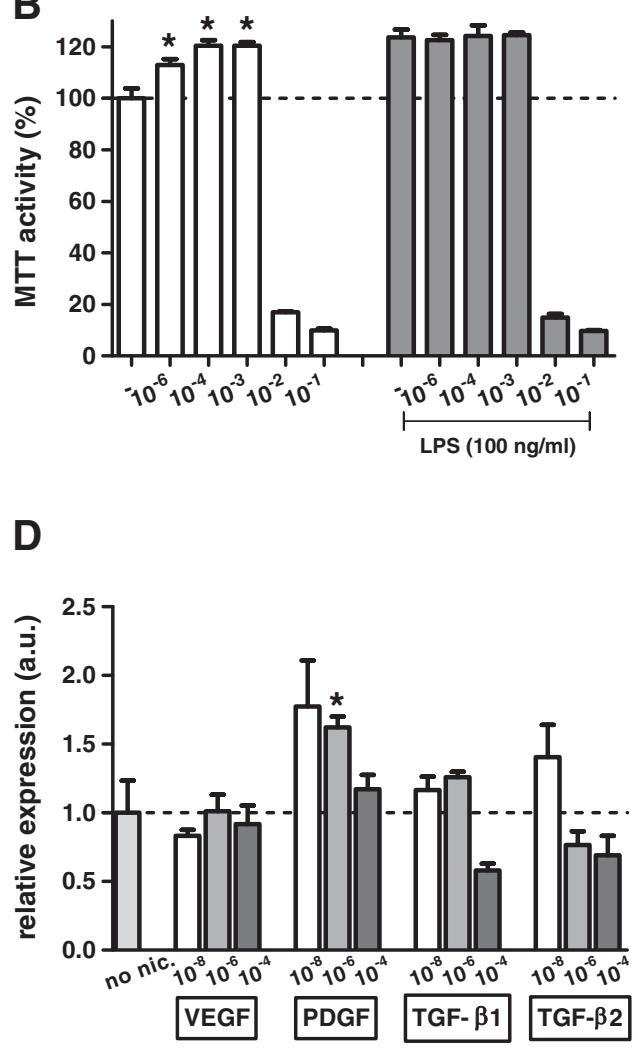

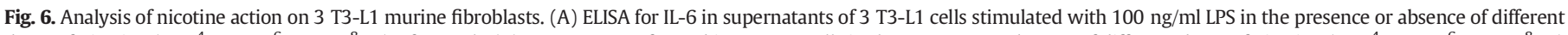

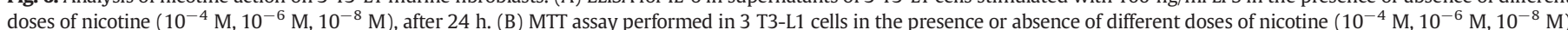

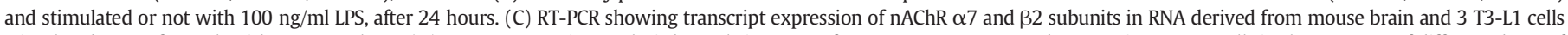

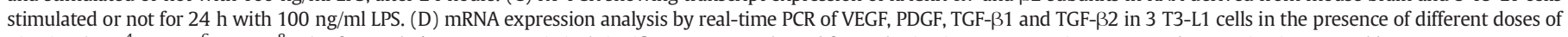
nicotine $\left(10^{-4} \mathrm{M}, 10^{-6} \mathrm{M}, 10^{-8} \mathrm{M}\right)$, after $24 \mathrm{~h}^{*}{ }^{*} p<0.05$. Statistical significance was evaluated for each nicotine concentration compared to no nicotine control by $t$-test. 


\subsection{Nicotinic acetylcholine receptor expression}

The anti-inflammatory effect of nicotine is considered to be mediated by the $\alpha 7 \mathrm{nAChR}$ expressed by many different cell types ranging from neurons to immune cells. Regarding the skin, the $\alpha 7 \mathrm{nAChR}$ has been detected in the upper spinous and granular layers of human scalp epidermis [34] and in skin of $\mathrm{BALB} / \mathrm{c}$ mice, where $\alpha 7 \mathrm{nAChR}$ positive staining was observed in epidermis, hair follicles, sebaceous glands, endothelial cells, resident dermal fibroblasts, but also in inflammatory cells like macrophages and PMNs during skin wound healing [35]. However, concerns have been raised regarding the specificity of anti- $\alpha 7 \mathrm{nAChR}$ antibodies due to the discrepancies in the results between immunodetection data and mRNA or genotyping results in $\alpha 7 \mathrm{nAChR}$ deficient mice $[22,36,37]$. Using three different primer pairs, we were unable to detect mRNA of $\alpha 7$ nAChR in either unwounded or wounded skin in C57BL/6 mice or in primary mouse cells or cell-lines. Our results are supported by similar studies that show presence of other nAChR transcripts like the $\beta 2$ nAChR but absence of the $\alpha 7$ nAChR mRNA in mouse alveolar [38,39], intestinal, splenic or peritoneal macrophages [22]. Since $\alpha 7$ nAChR has been detected in human monocytes, macrophages, endothelial cells $[6,10,12]$ but not in the corresponding mouse cells, it is likely that expression patterns of nicotinic acetylcholine receptors may differ between human and mouse tissues or between different mouse strains, and comparison of different studies or translation of mouse studies to humans should be done with caution.

Finally, to evaluate the effect of nicotine on additional cell types present in the skin, we have used the mouse vascular endothelial cell line SVEC4-10 and the 3 T3-L1 murine fibroblast cell line. In both cell types nicotine was found to have no effect on IL- 6 secretion, the only cytokine among TNF, IL-12 and IL-10 that was produced after LPS stimulation. However, we observed that nicotine induced a mild increase in cell proliferation in 3 T3-L1 fibroblasts under non-LPS stimulated conditions. This effect is potentially mediated by nicotinic acetylcholine receptor subunits expressed by fibroblasts that are different from $\alpha 7 \mathrm{nAChR}$ or $\beta 2 \mathrm{nAChR}$ since expression analysis indicated absence of these subunits in mouse 3 T3-L1 cells. Similar nicotine-induced stimulation in cell proliferation was noted by others in endothelial cells $[40,41]$, bone cells [42], epithelial cells [43], and chondrocytes [44].

Taken together, our results show that during the inflammatory phase of murine cutaneous wound healing, the main effect of nicotine administration was a negative regulation of growth factor expression, an effect which is likely to be due to reduced growth factor expression by wound macrophages. The inhibitory effect of nicotine on growth factor production may reflect, to a certain degree, the damaging effects of smoking on the skin vasculature and oxygenation and may provide critical insight into the overall detrimental effects of tobacco use in wound healing and general skin diseases.

\section{Funding}

This study was supported by internal funds of the Maastricht University Medical Centre.

\section{Acknowledgements}

We wish to thank Dr. M.P.J. de Winther (AMC, Amsterdam University) for providing us with the RAW 264.7 NF- $\kappa$ B luciferase reporter line and Dr. P.J. Lindsey (MUMC, Maastricht University) for help with statistical analysis.

\section{References}

[1] Singer AJ, Clark RA. Cutaneous wound healing. N Engl J Med 1999;341:738-46.

[2] Gurtner GC, Werner S, Barrandon Y, Longaker MT. Wound repair and regeneration. Nature 2008:453:314-21.
[3] Eming SA, Krieg T, Davidson JM. Inflammation in wound repair: molecular and cellular mechanisms. J Invest Dermatol 2007;127:514-25.

[4] Mahdavian Delavary B, van der Veer WM, van Egmond M, Niessen FB, Beelen RH. Macrophages in skin injury and repair. Immunobiology 2011;216:753-62.

[5] Lakhan SE, Kirchgessner A. Anti-inflammatory effects of nicotine in obesity and ulcerative colitis. J Transl Med 2011;9:129.

[6] Wang H, Yu M, Ochani M, Amella CA, Tanovic M, Susarla S, et al. Nicotinic acetylcholine receptor alpha7 subunit is an essential regulator of inflammation. Nature 2003;421:384-8.

[7] Borovikova LV, Ivanova S, Zhang M, Yang H, Botchkina GI, Watkins LR, et al. Vagus nerve stimulation attenuates the systemic inflammatory response to endotoxin. Nature 2000;405:458-62

[8] Wang H, Liao H, Ochani M, Justiniani M, Lin X, Yang L, et al. Cholinergic agonists inhibit HMGB1 release and improve survival in experimental sepsis. Nat Med 2004:10:1216-21.

[9] de Jonge WJ, van der Zanden EP, The FO, Bijlsma MF, van Westerloo DJ, Bennink RJ, et al. Stimulation of the vagus nerve attenuates macrophage activation by activating the Jak2-STAT3 signaling pathway. Nat Immunol 2005;6:844-51.

[10] Saeed RW, Varma S, Peng-Nemeroff T, Sherry B, Balakhaneh D, Huston J, et al. Cholinergic stimulation blocks endothelial cell activation and leukocyte recruitment during inflammation. J Exp Med 2005;201:1113-23.

[11] Heeschen C, Jang JJ, Weis M, Pathak A, Kaji S, Hu RS, et al. Nicotine stimulates angiogenesis and promotes tumor growth and atherosclerosis. Nat Med 2001;7:833-9.

[12] Heeschen C, Weis M, Aicher A, Dimmeler S, Cooke JP. A novel angiogenic pathway mediated by non-neuronal nicotinic acetylcholine receptors. J Clin Invest 2002;110:527-36.

[13] Misery L. Nicotine effects on skin: are they positive or negative? Exp Dermatol 2004; 13:665-70.

[14] Morimoto N, Takemoto S, Kawazoe T, Suzuki S. Nicotine at a low concentration promotes wound healing. J Surg Res 2008;145:199-204.

[15] Jacobi J, Jang JJ, Sundram U, Dayoub H, Fajardo LF, Cooke JP. Nicotine accelerates angiogenesis and wound healing in genetically diabetic mice. Am J Pathol 2002;161:97-104.

[16] Larson BJ, Longaker MT, Lorenz HP. Scarless fetal wound healing: a basic science review. Plast Reconstr Surg 2010;126:1172-80.

[17] Deliaert AE, Van den Kerckhove E, Tuinder S, Noordzij SM, Dormaar TS, van der Hulst RR. Smoking and its effect on scar healing. Eur J Plast Surg 2012;35:421-4.

[18] Carlsen H, Moskaug JO, Fromm SH, Blomhoff R. In vivo imaging of NF-kappa B activity. J Immunol 2002;168:1441-6.

[19] Henningfield JE, Stapleton JM, Benowitz NL, Grayson RF, London ED. Higher levels of nicotine in arterial than in venous blood after cigarette smoking. Drug Alcohol Depend 1993;33:23-9.

[20] Yoshikawa H, Kurokawa M, Ozaki N, Nara K, Atou K, Takada E, et al Nicotine inhibits the production of proinflammatory mediators in human monocytes by suppression of I-kappaB phosphorylation and nuclear factor-kappaB transcriptional activity through nicotinic acetylcholine receptor alpha7. Clin Exp Immunol 2006;146:116-23.

[21] Gilmore L. NF-kB Target Genes. Available: http://www.bu.edu/nf-kb/gene-resources/ target-genes/.

[22] van der Zanden EP, Snoek SA, Heinsbroek SE, Stanisor OI, Verseijden C, Boeckxstaens $\mathrm{GE}$, et al. Vagus nerve activity augments intestinal macrophage phagocytosis via nicotinic acetylcholine receptor alpha4beta2. Gastroenterology 2009;137:1029-39 (39 e1-4)

[23] Ulloa L. The vagus nerve and the nicotinic anti-inflammatory pathway. Nat Rev Drug Discov 2005:4:673-84.

[24] Konishi H, Wu J, Cooke JP. Chronic exposure to nicotine impairs cholinergic angiogenesis. Vasc Med 2010;15:47-54

[25] Conklin BS, Zhao W, Zhong DS, Chen C. Nicotine and cotinine up-regulate vascular endothelial growth factor expression in endothelial cells. Am J Pathol 2002;160:413-8.

[26] Zhen Y, Ruixing Y, Qi B, Jinzhen W. Nicotine potentiates vascular endothelial growth factor expression in balloon-injured rabbit aortas. Growth Factors 2008;26:284-92.

[27] Kanda Y, Watanabe Y. Nicotine-induced vascular endothelial growth factor release via the EGFR-ERK pathway in rat vascular smooth muscle cells. Life Sci 2007:80:1409-14.

[28] Ma L, Zwahlen RA, Zheng LW, Sham MH. Influence of nicotine on the biological activity of rabbit osteoblasts. Clin Oral Implants Res 2011;22:338-42.

[29] Klettner AK, Doths J, Roider J. Nicotine reduces VEGF-secretion and phagocytotic activity in porcine RPE. Graefes Arch Clin Exp Ophthalmol 2011;250:33-8.

[30] Shi D, Guo W, Chen W, Fu L, Wang J, Tian Y, et al. Nicotine promotes proliferation of human nasopharyngeal carcinoma cells by regulating alpha7AChR, ERK, HIF-1alpha and VEGF/PEDF signaling. PLoS One 2012;7:e43898.

[31] Lucas T, Waisman A, Ranjan R, Roes J, Krieg T, Muller W, et al. Differential roles of macrophages in diverse phases of skin repair. J Immunol 2010;184:3964-77.

[32] Lau PP, Li L, Merched AJ, Zhang AL, Ko KW, Chan L. Nicotine induces proinflammatory responses in macrophages and the aorta leading to acceleration of atherosclerosis in low-density lipoprotein receptor(-/-) mice. Arterioscler Thromb Vasc Biol 2006;26:143-9.

[33] Joe Y, Kim HJ, Kim S, Chung J, Ko MS, Lee WH, et al. Tristetraprolin mediates antiinflammatory effects of nicotine in lipopolysaccharide-stimulated macrophages. J Biol Chem 2011;286:24735-42.

[34] Kurzen H, Berger H, Jager C, Hartschuh W, Naher H, Gratchev A, et al. Phenotypical and molecular profiling of the extraneuronal cholinergic system of the skin. J Invest Dermatol 2004;123:937-49.

[35] Fan YY, Yu TS, Wang T, Liu WW, Zhao R, Zhang ST, et al. Nicotinic acetylcholine receptor alpha7 subunit is time-dependently expressed in distinct cell types during skin wound healing in mice. Histochem Cell Biol 2011;135:375-87. 
[36] Moser N, Mechawar N, Jones I, Gochberg-Sarver A, Orr-Urtreger A, Plomann $\mathrm{M}$, et al. Evaluating the suitability of nicotinic acetylcholine receptor antibodies for standard immunodetection procedures. J Neurochem 2007;102:479-92.

[37] Herber DL, Severance EG, Cuevas J, Morgan D, Gordon MN. Biochemical and histochemical evidence of nonspecific binding of alpha7nAChR antibodies to mouse brain tissue. J Histochem Cytochem 2004;52:1367-76.

[38] Matsunaga K, Klein TW, Friedman H, Yamamoto Y. Involvement of nicotinic acetylcholine receptors in suppression of antimicrobial activity and cytokine responses of alveolar macrophages to Legionella pneumophila infection by nicotine. J Immunol 2001;167:6518-24.

[39] Galvis G, Lips KS, Kummer W. Expression of nicotinic acetylcholine receptors on murine alveolar macrophages. J Mol Neurosci 2006;30:107-8.
[40] Zimmerman M, McGeachie J. The effect of nicotine on aortic endothelial cell turnover. An autoradiographic study. Atherosclerosis 1985;58:39-47.

[41] Villablanca AC. Nicotine stimulates DNA synthesis and proliferation in vascular endothelial cells in vitro. J Appl Physiol 1998;84:2089-98.

[42] Ramp WK, Lenz LG, Galvin RJ. Nicotine inhibits collagen synthesis and alkaline phosphatase activity, but stimulates DNA synthesis in osteoblast-like cells. Proc Soc Exp Biol Med 1991;197:36-43.

[43] Mazhari NJ, Mandal AK, Thusoo TK. Carcinogenic effect of nicotine on normal mammary ductal epithelial cells and the protective role of beta-carotene. Indian J Pathol Microbiol 2003;46:24-7.

[44] Ying X, Cheng S, Shen Y, Cheng X, An Rompis F, Wang W, et al. Nicotine promotes proliferation and collagen synthesis of chondrocytes isolated from normal human and osteoarthritis patients. Mol Cell Biochem 2012;359:263-9. 